Article

\title{
Body Adiposity Index Performance in Estimating Body Fat Percentage in Colombian College Students: Findings from the FUPRECOL-Adults Study
}

Robinson Ramírez-Vélez ${ }^{1}{ }^{*}$, Jorge Enrique Correa-Bautista ${ }^{1}$, Katherine González-Ruíz ${ }^{2}$, Andrés Vivas ${ }^{2}$, Héctor Reynaldo Triana-Reina ${ }^{3}$, Javier Martínez-Torres ${ }^{3}$, Daniel Humberto Prieto-Benavides ${ }^{1}$, Hugo Alejandro Carrillo ${ }^{4}$, Jeison Alexander Ramos-Sepúlveda ${ }^{5}$, Emilio Villa-González ${ }^{6,7}$ and Antonio García-Hermoso ${ }^{8}$

1 Centro de Estudios para la Medición de la Actividad Física CEMA, Escuela de Medicina y Ciencias de la Salud, Universidad del Rosario, Bogotá 111221, Colombia; jorge.correa@urosario.edu.co (J.E.C.-B.); danielprietob@gmail.com (D.H.P.-B.)

2 Grupo de Ejercicio Físico y Deportes, Vicerrectoría de Investigaciones, Universidad Manuela Beltrán, Bogotá 110231, Colombia; katherine.gonzalez@docentes.umb.edu.co (K.G.-R.);

jose.vivas@docentes.umb.edu.co (A.V.)

3 Grupo GICAEDS, Facultad de Cultura Física, Deporte y Recreación, Universidad Santo Tomás, Bogotá 110311, Colombia; hectortriana@usantotomas.edu.co (H.R.T.-R.); javiermartinezt@usantotomas.edu.co (J.M.-T.)

4 Grupo GRINDER, Programa de Educación Física y Deportes, Universidad del Valle, Santiago de Cali 76001, Colombia; hugo.carrillo@correounivalle.edu.co

5 Facultad de Educación a Distancia y Virtual, Institución Universitaria Antonio José Camacho, Santiago de Cali 760045, Colombia; jalexanderramos@admon.uniajec.edu.co

6 Department of Education Sciences, University of Almería, Almería 04120, Spain; evilla@unach.edu.ec

7 PROFITH “PROmoting FITness and Health through Physical Activity" Research Group, Department of Physical Education and Sport, School of Sport Sciences, University of Granada, Granada 18010, Spain

8 Laboratorio de Ciencias de la Actividad Física, el Deporte y la Salud, Universidad de Santiago de Chile, USACH, Santiago 7500618, Chile; antonio.garcia.h@usach.cl

* Correspondence: robin640@hotmail.com or robinson.ramirez@urosario.edu.co; Tel.: +57-1-297-0200 (ext. 3428)

Received: 19 December 2016; Accepted: 29 December 2016; Published: 17 January 2017

Abstract: Recently, a body adiposity index $\left(\mathrm{BAI}=(\right.$ hip circumference $\left.) /((\text { height })(1.5))^{-18}\right)$ was developed and validated in adult populations. The aim of this study was to evaluate the performance of BAI in estimating percentage body fat (BF\%) in a sample of Colombian collegiate young adults. The participants were comprised of 903 volunteers $(52 \%$ females, mean age $=21.4$ years \pm 3.3 ). We used the Lin's concordance correlation coefficient, linear regression, Bland-Altman's agreement analysis, concordance correlation coefficient $(\rho c)$ and the coefficient of determination $\left(R^{2}\right)$ between $\mathrm{BAI}$, and $\mathrm{BF} \%$; by bioelectrical impedance analysis (BIA)). The correlation between the two methods of estimating $\mathrm{BF} \%$ was $R^{2}=0.384, p<0.001$. A paired-sample $t$-test showed a difference between the methods (BIA BF\% $=16.2 \pm 3.1, \mathrm{BAI} B F \%=30.0 \pm 5.4 \% ; p<0.001$ ). For BIA, bias value was $6.0 \pm 6.2 \mathrm{BF} \%(95 \%$ confidence interval $(\mathrm{CI})=-6.0$ to 18.2$)$, indicating that the BAI method overestimated $\mathrm{BF} \%$ relative to the reference method. Lin's concordance correlation coefficient was poor $(\rho c=0.014,95 \% C I=-0.124$ to $0.135 ; p=0.414)$. In Colombian college students, there was poor agreement between BAI- and BIA-based estimates of $\mathrm{BF} \%$, and so BAI is not accurate in people with low or high body fat percentage levels.

Keywords: body composition; validity; students; body adiposity 


\section{Introduction}

Obesity has reached an epidemic proportion, being the main cause of death and disability around the world [1]. Excess adipose tissue is associated with cardiovascular disease (CVD) risk factors such as hypertension, diabetes mellitus and dyslipidaemia [2-4]. National trends in CVD risk factors show that although there have been marginal improvements in all weight groups, risk factors continue to be higher in obese and overweight subjects $[5,6]$.

A simple and effective measure of adiposity is needed to enable us to estimate the magnitude of the problem and development appropriate management and preventive strategies. Various methods can be used, such as magnetic resonance imaging (MRI), computed tomography, dual-energy X-ray absorption (DEXA), isotopic measurement of body water, whole body plethysmography, bioelectrical impedance analysis (BIA) and underwater weighing [6]. Although these methods of assessing adiposity are accurate, non-invasive, rapid and reliable, they are not routinely used in clinical practice because of their cost. Anthropometric methods of assessing body composition based on measurements of weight, height and body circumference have been used as an alternative to laboratory methods [7]. All these indicators are simple, inexpensive, non-invasive methods that have been validated for use in clinical practice and epidemiological research [8]. In 2011, a new anthropometric indicator was proposed, the Body Adiposity Index (BAI). The BAI is derived from hip circumference and height and was intended to be a direct validated method of estimating body fat percentage (BF\%), which was developed in a sample of Mexican Americans and validated in African-American adults [9]. However, validation studies done in populations of various ethnicities have consistently indicated that the BAI tends to overestimate adiposity at lower $\mathrm{BF} \%$, and underestimate adiposity at higher BF\% [10-13]. Specifically, BAI does not provide valid estimates of BF\% in Caucasian, European or European-American adults [14-17].

Validation studies in Costa Rica [18] and Brazil [19], based on 199 college students (mean age $18.6 \pm 2.4$ years) and 706 individuals (mean age 37.3 years \pm 12.1 ), respectively, showed that BAI cannot be recommended as a predictor of $\mathrm{BF} \%$ in these Latin-American populations [20]. Given the risk of over-nutrition in developing countries, it is necessary to measure its prevalence in vulnerable populations, such as Latin-American adults, in order to identify high-risk groups and develop preventive interventions [7]. At present, there are few global reports on the prevalence of overweight individuals and obesity for low- to middle-income countries experiencing rapid nutrition transitions, such as those in Latin America and Africa [7], although assessment of body composition is of crucial importance in these countries because of the relatively high prevalence of both underweight and overweight [21-24].

Since the index was developed in samples of Mexican-American and African-American individuals, the effectiveness of BAI as an alternative method of estimating $\mathrm{BF} \%$ and the validity of BAI as a predictor of risk of cardiovascular disease in other ethnicities needs further investigation. As far as we know, our study is the first to analyze the validity of BAI to use as an alternative measure for BMI in Colombian collegiate students in a large cohort and in both genders. The aim of this study was to evaluate the performance of $\mathrm{BAI}$ in estimating $\mathrm{BF} \%$ in a sample of Colombian college students, with BIA used as the reference method.

\section{Methods}

\subsection{Participants}

We implemented the cross-sectional component of the FUPRECOL study (Association between Muscular Strength and Metabolic Risk Factors in Colombia) in Bogota, Colombia, during the 2013-2014 college year $[25,26]$. We recruited a convenience sample consisting of 903 volunteers $(51.9 \%$ females, mean age $=21.4$ years \pm 3.3 ; range $18-35$ ) who were of low-to-middle socioeconomic status (SES) (i.e., in classes 1 to 4 of the six-class scheme defined by the Colombian government) and were enrolled in public or private university in the capital district of Bogota and Cali, Colombia. Students were 
informed that participation was voluntary and that there was no penalty for not participating. Inclusion criteria were: no self-reported history of inflammatory joint disease or neurological disorder; not an elite athlete. Participants were not compensated. Exclusion criteria were: a medical or clinical diagnosis of a major systemic disease (including malignant conditions such as cancer); type 1 or 2 diabetes; high blood pressure; hypothyroidism or hyperthyroidism; a history of drug or alcohol abuse; regular use of multivitamins; inflammation related to trauma or contusions; infectious conditions; BMI (body mass index: weight in $\mathrm{kg} /$ height in $\mathrm{m}^{2}$ ) $\geq 35$. The institutional ethics committee approved the study (Universidad Manuela Beltrán No. 01-1802-2013) in accordance with the latest version of the Declaration of Helsinki. After providing written, informed consent to participation, volunteers were given an appointment for a testing session at the University laboratories.

\subsection{Procedures}

Each participant was asked to complete a health questionnaire and we also collected sociodemographic data and information about personal and family pathological background. After completing the questionnaire, participants were instructed to change into shorts and a t-shirt and remove any metal or jewelry from their persons. Anthropometric variables were assessed by a nutritionist in accordance with the International Society for the Advancement of Kinanthropometry guidelines [27]. Data were collected in the morning, in a single session after a fast of approximately $12 \mathrm{~h}$, by a single trained and experienced evaluator. Body weight was measured with participants barefoot in their underwear, using electronic scales (Model Tanita ${ }^{\circledR}$ BC 420MA, Tokyo, Japan). Height was measured using a mechanical stadiometer platform (Seca ${ }^{\circledR}$ 274, Hamburg, Germany). We calculated BMI from the height and weight measurements. Weight status was determined according to World Health Organization (WHO) criteria for obesity (BMI $\geq 30$ ) and overweight (BMI $\geq 25)$ [28]. Waist circumference (WC; in $\mathrm{cm}$ ) was measured using a tape measure, at the smallest point between the lower costal border and the iliac crest; where this was not evident, it was measured at the midpoint between the last rib and the iliac crest (Ohaus ${ }^{\circledR}$ 8004-MA, Parsippany, NJ, USA). Hip circumference (in $\mathrm{cm}$ ) was measured at the largest point around the buttocks with the tape horizontal and parallel to the ground using a tape with $0.1 \mathrm{~mm}$ accuracy (Ohaus ${ }^{\circledR}$ 8004-MA, Parsippany, NJ, USA). A tetrapolar whole body impedance meter (Model Tanita ${ }^{\circledR}$ BC 420MA, Tokyo, Japan) was used to perform the analysis of $\mathrm{BF} \%$, similar to previous studies [7,8]. Measurements were made with the participant in a standing position with arms and legs lying parallel to the trunk and separated, so that the thighs were not touching. Before testing, participants were required to adhere to these BIA manufacturer's instructions [29]: (i) to not eat or drink within $4 \mathrm{~h}$ of the test; (ii) to not consume caffeine or alcohol within $12 \mathrm{~h}$ of the test; (iii) to not take diuretics within 7 days of the test; (iv) to not do physical exercise within $12 \mathrm{~h}$ of the test, and; (v) to urinate within $30 \mathrm{~min}$ of the test. An electrical current of $50 \mathrm{kHz}$ was passed through the participant and resistance and reactance were measured. To ensure data quality, the equipment was calibrated daily using a known calibration standard, in accordance with the manufacturer's instructions [29]. BAI was calculated from hip circumference and height as follow: BAI $(\mathrm{BF} \%)=(\text { hip circumference }[\mathrm{cm}] / \text { height }[\mathrm{m}] 1.5)^{-18}$ [9]. We also calculated the waist-to-hip ratio (WHtR).

\subsection{Statistical Analysis}

Statistical analyses were performed using Statistical Package for the Social Sciences software for Windows version 21.0 (IBM Corporation, New York, NY, USA). The Kolmogorov-Smirnov test was used to assess the distributions of variables; $p$-values $<0.05$ were considered significant. Statistical analysis consisted of a description of the variables (mean, standard deviation (SD)) and $t$-tests or Chi Square test to check for differences in means or proportions, respectively. The BIA method was treated as the gold standard method. We used separate paired-sample $t$-tests to assess differences between the two methods of estimating $\mathrm{BF} \%$ for each gender, level of adiposity and weight status. Lin's concordance correlation coefficient was used to assess the concordance between BAI and BIA 
separately for males and females [30]. The methods used to assess the relationships between $\% \mathrm{BF}_{\mathrm{BIA}}$ and $\% \mathrm{BF}_{\mathrm{BAI}}$ stratified by gender at different stages were the Bland-Altman analysis, multiple regression analysis and coefficient of determination $\left(R^{2}\right)$ [31].

\section{Results}

Descriptive statistics and between-gender comparisons are shown in Table 1. All of the anthropometric variables, except hip, BMI and BMI $\geq 30\left(\mathrm{~kg} / \mathrm{m}^{2}\right)$, were different in males than in females $(p<0.001)$.

Table 1. Characteristics of study subjects as a whole and by gender.

\begin{tabular}{ccccc}
\hline Characteristics & Women $(\boldsymbol{n}=\mathbf{4 6 9 )}$ & Men $(\boldsymbol{n}=\mathbf{4 3 4 )}$ & Total $(\boldsymbol{n}=\mathbf{9 0 3})$ & $p$ \\
\hline Age $($ years $)$ & $21.5(3.2)$ & $21.3(3.4)$ & $21.4(3.3)$ & 0.478 \\
Height $(\mathrm{m})$ & $1.60(0.10)$ & $1.72(0.07)$ & $1.66(0.11)$ & 0.001 \\
Weight $(\mathrm{kg})$ & $58.9(10.0)$ & $69.9(12.5)$ & $64.2(12.5)$ & 0.001 \\
Waist $(\mathrm{cm})$ & $72.0(8.1)$ & $79.1(9.8)$ & $75.4(9.6)$ & 0.001 \\
Hip $(\mathrm{cm})$ & $97.0(8.8)$ & $97.5(9.5)$ & $97.2(9.1)$ & 0.480 \\
WHtR & $0.45(0.05)$ & $0.46(0.06)$ & $0.45(0.05)$ & 0.035 \\
BF\% & $26.8(7.2)$ & $16.0(6.7)$ & $21.6(8.8)$ & 0.001 \\
BF\% ${ }_{\text {BAI }}^{2}$ & $30.0(5.4)$ & $24.8(5.5)$ & $27.5(6.0)$ & 0.001 \\
BMI $\left(\mathrm{kg} / \mathrm{m}^{2}\right)$ & $23.0(3.7)$ & $23.5(3.7)$ & $23.2(3.7)$ & 0.097 \\
$\mathrm{BMI} \geq 30\left(\mathrm{~kg} / \mathrm{m}^{2}\right)$ & $26[5.5]$ & $23[5.2]$ & $49[5.4]^{*}$ & 0.816 \\
\hline
\end{tabular}

Data are expressed as mean (SD) or $n$ [\%]. $p$-values are given for comparison between women and men. Significant between-gender differences by $t$-test or chi-square *. BIA $=$ bioelectrical impedance analysis; $\mathrm{SD}=$ standard deviation

In both males and females, Lin's concordance correlation coefficient for the association between $\mathrm{BF} \%{ }_{\mathrm{BAI}}$ and $\mathrm{BF} \%{ }_{\mathrm{BIA}}$ was poor, $\rho c=0.021(95 \% \mathrm{CI}=-0.174$ to $0.184 ; p=0.408)$ and $\rho c=0.029$ $(95 \% \mathrm{CI}=-0.174$ to $0.196 ; p=0.381)$, respectively. Males and females were then grouped according to $\mathrm{BF} \%$ and, as shown in Table 2, BAI underestimated BF\% at all levels of adiposity and weight status. In females, a paired-samples $t$-test revealed a difference between the two methods of estimating $\mathrm{BF} \%$ (difference in means $=-3.1$ (CI 95\% -3.7 to -2.6); BAI 30.0 [5.4]\% vs. BIA 26.8 [7.2] $\% p<0.001$ ). In males, a paired-samples $t$-test revealed a difference between the two methods of estimating $\mathrm{BF} \%$ (difference in means $=-8.7$ (CI 95\% -9.3 to -8.1 ); BAI 24.8 [5.5]\% vs. BIA 16.0 [6.7]\%, $p<0.001$ ). Significant differences were found in both genders in students with BMI greater than $25(p<0.01)$.

The Bland-Altman plot (Figure 1) showed that BAI overestimated BF\% relative to BIA in males (Figure 1A), females (Figure 1B) and the combined sample (Figure 1C). In men, the bias of the BAI was 9.1 (SD 4.8) $\mathrm{BF} \%(95 \% \mathrm{CI}=-0.2$ to 18.5$)$. In women, the bias of the BAI was $3.2(\mathrm{SD} 6.0) \mathrm{BF} \%$ $(95 \% \mathrm{CI}=-8.5$ to -15.0$)$. In the combined sample, the bias of the BAI was $6.0(\mathrm{SD} 4.3) \mathrm{BF} \%$ (95\% CI $=-6.0$ to 18.2 ), indicating that the BAI method significantly overestimated $\mathrm{BF} \%$ relative to the BIA method. The slopes in Figure 1 show that the correlation between the differences in BAI and BIA, as well as the mean $\mathrm{BF} \%$ measured using both methods, was higher in females $(\mathrm{r}=0.530$, $p<0.001)$ than in males $(r=0.461, p<0.001)$. 
Table 2. Body fat percentage by BAI and BIA according to different levels of adiposity and weight status by gender.

\begin{tabular}{|c|c|c|c|c|c|c|c|c|c|c|c|c|}
\hline \multirow[b]{2}{*}{ Characteristics } & \multicolumn{6}{|c|}{ Female } & \multicolumn{6}{|c|}{ Male } \\
\hline & $n$ & BF\% ${ }_{\text {BAI }}$ & BF\% ${ }_{\text {BIA }}$ & $p$-Value & $\begin{array}{l}\text { Difference between } \\
\text { Measures (CI 95\%) }\end{array}$ & $R^{2}$ & $n$ & $\mathrm{BF} \%_{\mathrm{BAI}}$ & BF $\%_{\text {BIA }}$ & $p$-Value & $\begin{array}{l}\text { Difference between } \\
\text { Measures (CI 95\%) }\end{array}$ & $R^{2}$ \\
\hline All & 469 & $30.0(5.4)$ & $26.8(7.2)$ & 0.001 & $-3.1(-3.7$ to -2.6$)$ & 0.280 & 434 & $24.8(5.5)$ & $16.0(6.7)$ & 0.001 & $-8.7(-9.3$ to -8.1$)$ & 0.212 \\
\hline \multicolumn{13}{|l|}{$\begin{array}{c}\text { Level of } \\
\text { adiposity }(\%) *\end{array}$} \\
\hline$\leq 20$ & 87 & $26.5(2.9)$ & $16.2(3.1)$ & 0.001 & $-10.3(-11.1$ to -9.4$)$ & 0.041 & 332 & $23.8(3.9)$ & $13.1(4.1)$ & 0.001 & $-10.7(-11.1$ to -10.2$)$ & 0.283 \\
\hline $20-30$ & 235 & $29.1(5.7)$ & $25.6(2.8)$ & 0.001 & $-3.4(-4.1$ to -2.6$)$ & 0.046 & 88 & $27.7(6.4)$ & $24.0(2.5)$ & 0.001 & $-3.5(-5.1$ to -2.3$)$ & 0.024 \\
\hline $31-40$ & 127 & $32.9(3.5)$ & $33.8(2.6)$ & 0.002 & $0.9(0.3$ to -1.4$)$ & 0.241 & 14 & $27.5(14.2)$ & $33.3(2.4)$ & 0.196 & $5.7(-3.3$ to -14.9$)$ & 0.081 \\
\hline$\geq 40$ & 20 & $36.7(2.9)$ & $42.1(1.6)$ & 0.001 & $5.4(4.0$ to 6.8$)$ & 0.114 & - & - & - & - & - & - \\
\hline \multicolumn{13}{|l|}{ Weight status } \\
\hline $\begin{array}{l}\mathrm{BMI}<25 \\
\left(\mathrm{~kg} / \mathrm{m}^{2}\right)\end{array}$ & 348 & $28.5(4.9)$ & $24.5(5.1)$ & 0.001 & $-4.0(-4.6$ to -3.3$)$ & 0.051 & 307 & $23.4(4.4)$ & $13.3(4.4)$ & 0.001 & $-10.0(-10.6$ to -9.4$)$ & 0.087 \\
\hline $\begin{array}{c}25 \leq \mathrm{BMI}<30 \\
\left(\mathrm{~kg} / \mathrm{m}^{2}\right)\end{array}$ & 94 & $34.0(2.4)$ & $33.4(3.7)$ & 0.001 & $-5.5(-1.5$ to -0.4$)$ & 0.014 & 104 & $27.4(5.9)$ & $21.7(4.1)$ & 0.001 & $-5.6(-7.1$ to -4.1$)$ & 0.018 \\
\hline $30 \leq \mathrm{BMI}<35$ & 27 & $37.9(2.9)$ & $40.4(3.2)$ & 0.001 & $-2.4(0.8$ to 4.1$)$ & 0.003 & 23 & $32.2(4.3)$ & $29.1(6.7)$ & 0.009 & $-3.1(-5.5$ to -0.8$)$ & 0.365 \\
\hline
\end{tabular}

Data are expressed as mean (SD). * Levels of adiposity (20-30; 31-40 and $\geq 40$ BF\%) were classified according to the National Health and Nutrition Examination Survey (NHANES) (1999-2004) by BIA in Spanish population [21]. CI = confidence interval. 
A. Male

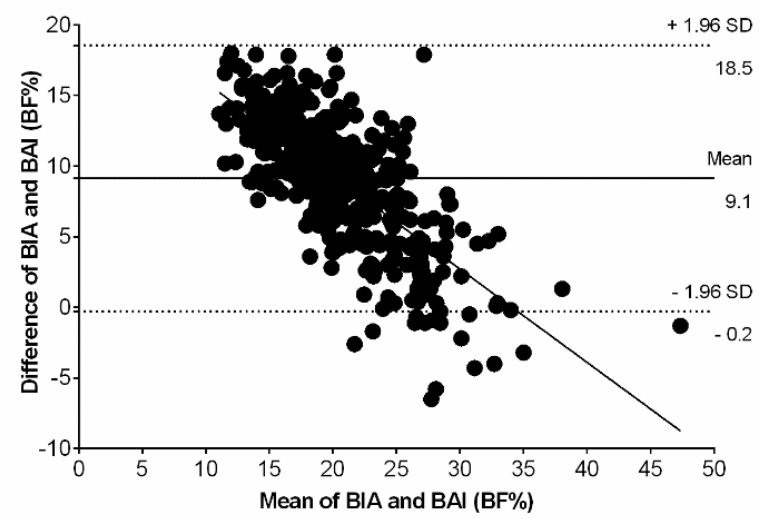

B. Female

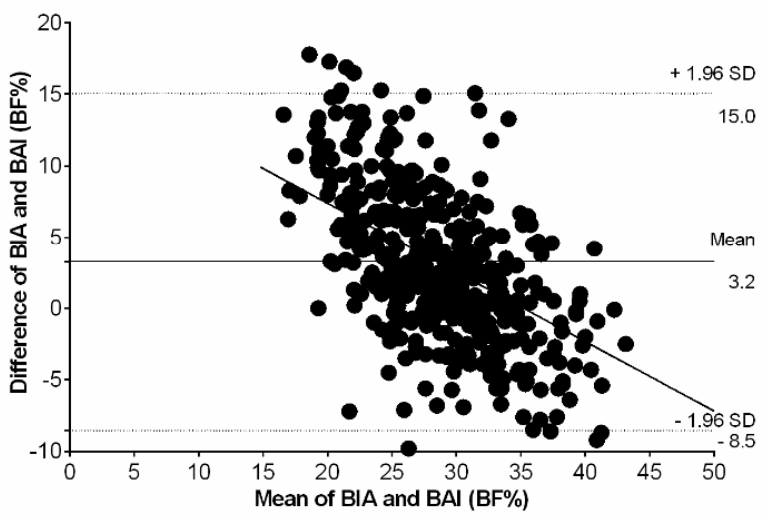

C. Total

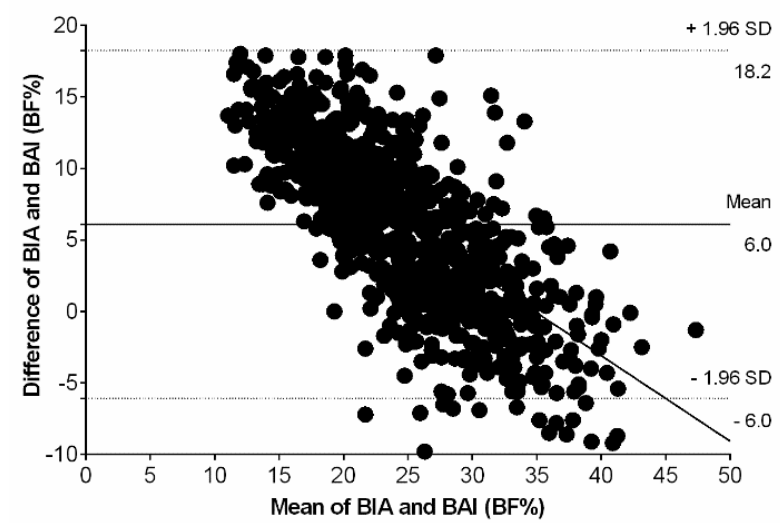

Figure 1. Bland-Altman plots with mean and $95 \%$ limits of agreement for comparing $\mathrm{BF} \%{ }_{\mathrm{BAI}}$ and $\mathrm{BF} \%_{\mathrm{BIA}}$ among males (A), females (B), and total (C). The central line represents the mean bias between $\mathrm{BF} \%_{\mathrm{BAI}}$ and $\mathrm{BF} \%{ }_{\mathrm{BIA}}$; the outer lines represent $95 \%$ limits.

Brand-Altman plots stratified by gender and weight status showed that, in individuals of normal weight (Figure 2), the BAI overestimated BF\% relative to BIA in males (Figure 2A), females (Figure 2B), and the whole sample (Figure 2C). Bland-Altman plots for the overweight group (middle panel) showed that the BAI overestimated $\mathrm{BF} \%$ relative to BIA in men and in the combined sample; however, in the obese group (right panel), the BAI underestimated $\mathrm{BF} \%$ relative to BIA in both genders. 

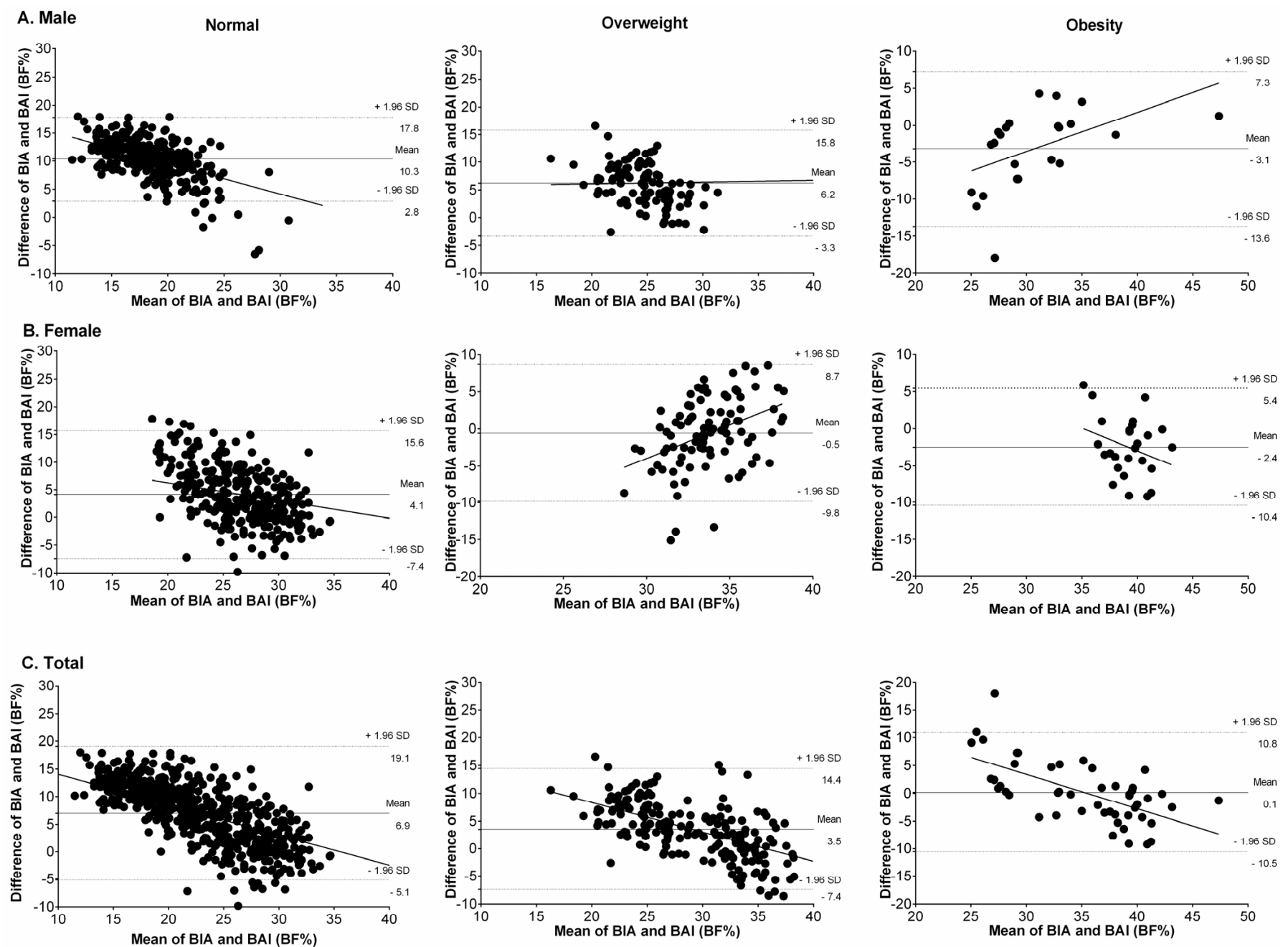

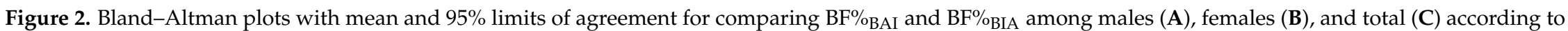
weight status (normoweight, overweight and obesity). The central line represents the mean bias between $\mathrm{BF} \% \mathrm{BAI}$ and $\mathrm{BF} \% \mathrm{BIA}_{\mathrm{B}}$, the outer lines represent $95 \%$ limits. 


\section{Discussion}

The purpose of the study was to assess the performance of BAI as an estimator of $\mathrm{BF} \%$ in a sample of Colombian college students. The main finding was the BAI's lack of predictive validity as a method of estimating $\mathrm{BF} \%$ in both genders relative to $\mathrm{BIA}$ ( $\mathrm{bias}=6.0 \%$ ). The Bland-Altman plots showed that BAI tended to overestimate adiposity in males (bias $=9.1$ ) and females (bias $=3.2$ ) relative to the criterion measure, namely BIA. Another finding was that BAI overestimated BF\% in both genders, particularly in participants with a higher level of adiposity and in heavier participants. We concluded, therefore, that BAI does not seem to be appropriate to determine BF\% in the Colombian young adult population.

Although it has been suggested $[9,32]$ that BAI can provide an estimate of $\mathrm{BF} \%$ without further adjustment, our results indicate that these estimates are systematically biased by gender, level of adiposity and weight status. We agree with Freedman et al. [33] that analyses of body fatness that do not control for gender should be treated with caution. As females are generally shorter than males and have more $\mathrm{BF} \%$, an analysis of the association between height and $\mathrm{BF} \%$ would greatly overstate the strength of the association. In our study, overall BAI overestimated BF\% by $6.0 \%$, a level of bias that is fairly similar to that reported in 623 European-American adults who participated in the Fels Longitudinal Study [34] and in a study [33] of 1151 adults that was based at the Body Composition Unit of the New York Obesity Nutrition Research Center. We found that in both genders, BAI overestimated $\mathrm{BF} \%$ by about $3.5 \%$; this may have been due to the fact that our participants tended to be overweight (mean BMI = 26.8 \pm 1.4 ). Due to differences between measurements that vary substantially according to level of adiposity, weight status and gender (Table 3), one would expect observed gender differences to vary across studies according to the participants' adiposity. Ethnicity is another factor that greatly influences shape and body composition. Earlier studies based on samples of various ethnicities, such as European Americans [9], Mexican Americans [32], African Americans [33] and Latin Americans [10,15,25], showed that the BAI overestimates BF\% at lower levels of adiposity. Similar to our study, some other studies have shown that the BAI overestimates BF\% at higher levels of adiposity [10-12]; however, there are also reports that BAI underestimates $\mathrm{BF} \%$ at higher levels of adiposity $[35,36]$. It is difficult to compare the results of this study with those of earlier studies, as the earlier studies used a variety of different measurement devices such as foot-to-foot BIA, devices with adhesive tape and multi-frequency devices.

An assessment of the validity of $\mathrm{BAI}$ as an estimator of $\mathrm{BF} \%$ in severely obese individuals [11] using BIA as the reference method found large individual errors in predictions of $\mathrm{BF} \%$. Another study of 19 severely obese, non-diabetic females awaiting bariatric surgery [10] showed that the BAI underestimated $\mathrm{BF} \%$ by up to $2.2 \%$ relative to BIA. In contrast, in a sample of Costa Rican students, BAI under- and over-estimated BF\% relative to DEXA in females and males, respectively [18]. Even in a population of young adults, BAI- and BIA-based BF\% estimates were only weakly correlated [12]. The findings of these studies, together with our results, suggest that when using the BIA method of measuring $\mathrm{BF} \%$, clinicians and exercise scientists should report details of the procedure and equipment used to avoid misinterpretation of findings. Lohman [37] considered an error of $4 \%$ in estimates of $\mathrm{BF} \%$ to be reasonable. This may suggest the need to validate field methods commonly used in this environment with other laboratory tests. The reasons for the discrepancy between BAI and BIA are not clear, but as the BAI quantifies adiposity based on height-adjusted hip circumference, differences in the distribution of body fat may be reflected in BAI [38]. Regarding the difference between genders, females have higher levels of body fat than males and their BF\% is differently distributed [25], whilst males tend to be taller [25]. Ethnic differences in anthropometric profile and body composition can change the relationship between anthropometric measurements and $\mathrm{BF} \%$, meaning that an equation derived from research in one population is invalid in other populations. In addition, weaker associations have been reported between cardiovascular risk factors and BF\% by BAI than with WC, WhtR, and BMI [25,39]. 
Table 3. Comparison of BAI in different trials.

\begin{tabular}{|c|c|c|c|c|c|}
\hline Study & Sample & Age (Years) & Device & $\begin{array}{l}\text { Agreement between } \\
\text { Measurement Methods/Bias }\end{array}$ & Main Finding \\
\hline Present study & $\begin{array}{l}903 \text { apparently healthy and } \\
\text { sub-sample with } \\
\text { overweight/obese }\end{array}$ & Mean age $21.4 \pm 3.3$ & Tetrapolar frequency & $\begin{array}{l}\text { Bland-Altman plots Male bias } \\
9.1 \% \text {, Female bias } 3.2 \% \text {, } \\
\text { Total bias } 6.0 \%\end{array}$ & $\begin{array}{l}\text { Overall, } \mathrm{BAI} \text { overestimating } \mathrm{BF} \% \text {, } \\
\text { in overweight subjects the } \mathrm{BAI} \\
\text { overestimated } \mathrm{BF} \% \text {, and obese group the } \\
\mathrm{BAI} \text { underestimated } \mathrm{BF} \% \text { both genders. }\end{array}$ \\
\hline Geliebter et al. [10] & $\begin{array}{l}19 \text { pre-bariatric surgery clinically } \\
\text { severe obese, non-diabetic } \\
\text { females }\end{array}$ & Mean age $32.6 \pm 7.7$ & Tetrapolar frequency & Bland-Altman plots Bias $2.2 \%$ & BAI underestimating BF\% \\
\hline Bernhard et al. [11] & 240 patients with severe obesity & Mean age $44.1 \pm 11.1$ & A single-frequency & $\begin{array}{l}\text { Intraclass correlation } 0.74 ; 95 \% \\
\text { confidence interval }=0.68-0.79\end{array}$ & $\begin{array}{l}\text { The two methods were similar according } \\
\text { to the intraclass correlation }\end{array}$ \\
\hline Ezeukwu et al. [12] & 30 obese females & Mean age $22.8 \pm 3.3$ & A single-frequency & Bland-Altman plots Bias $15.0 \%$ & BAI underestimating $\mathrm{BF} \%$ \\
\hline Lemacks et al. [36] & $\begin{array}{l}187 \text { overweight/obese } \\
\text { postmenopausal females }\end{array}$ & Mean age $55.8 \pm 3.3$ & Dual-energy X-ray & $\begin{array}{l}\text { Concordance correlation } \\
\text { coefficient } \rho \mathrm{c}=0.39\end{array}$ & $\begin{array}{l}\text { Poor agreement strength between } \\
\text { Dual-energy X-ray (DEXA) BF\% and BAl } \\
\text { overestimating BF\% }\end{array}$ \\
\hline Vinknes et al. [35] & $\begin{array}{l}5193 \text { middle-aged ( } 47-49 \text { years) } \\
\text { and elderly ( } 71-74 \text { years) males } \\
\text { and females }\end{array}$ & Mean range $47-72$ & Dual-energy X-ray & $\begin{array}{l}\text { Bland-Altman plots Bias in } \\
\text { subjects with lower BF\% } 6.0 \% \text {, } \\
\text { Bias in subjects with higher } \\
\text { BF\% } 1.9 \%\end{array}$ & $\begin{array}{l}\text { BAI overestimated adiposity in subjects } \\
\text { with lower BF\% (particularly in males) } \\
\text { and underestimated it in overweight and } \\
\text { obese subjects }\end{array}$ \\
\hline
\end{tabular}


Our study has several important limitations. Cross-sectional design limits causal inferences. We have used the BIA as the "gold standard" for adiposity and not the DEXA method. Furthermore, factors that may affect the results are water retention, use of diuretics, hydration status, menstrual cycle, level of BF\% and ethnicity, which may also represent a limitation of the use of BIA [40]. Overall, BIA is a useful tool for clinical studies and large epidemiological studies with diverse populations, particularly in Latin-American nations; however, for individual assessment of fat mass, BIA has limited use $[41,42]$. Therefore, the results that we found must be verified in other age classes and for BMI groups higher than $35 \mathrm{~kg} / \mathrm{m}^{2}$. Finally, we have not considered the potential impact of recognized determinants, such as socioeconomic status, metabolic biomarkers, physical activity patterns, and physical fitness, which modulate growth and levels of adiposity. The strengths of our study include a large sample size and an equal ratio of males to females.

\section{Conclusions}

In summary, the BAI is not recommended as a method of estimating BF\% in young adults from Colombia. The extrapolation of an equation for estimating BF\% based on measurements of hip and height for the Colombian population should be viewed with caution due to Colombian ethnicity being composed of a mixture of Amerindians, Europeans, and Africans, one of the most heterogeneous populations in the world, and conferring their peculiar characteristics. The BAI does not appear to be a good alternative to the usual anthropometric indicators of obesity such as waist or hip circumference, WHtR and BMI. We emphasize the importance of a simple and inexpensive method for adiposity estimation in LMICs where sophisticated equipment is not widely availability. Further epidemiological studies examining the utility of BAI for Latin-American populations are still needed for a better understanding of the validity of this new index.

Acknowledgments: This study was part of the project entitled "Body Adiposity Index and Biomarkers of Endothelial and Cardiovascular Health in Adults", which was funded by the Centre for Studies on Measurement of Physical Activity, School of Medicine and Health Sciences, Universidad del Rosario (Code No. FIUR DN-BG001). The funder had no role in the study design, data collection, data analysis and interpretation, preparation of the manuscript, or decision to publish.

Author Contributions: Robinson Ramírez-Vélez, Katherine González-Ruíz, and Jorge Enrique Correa-Bautista conceived and designed the study, and analyzed the data; Daniel Humberto Prieto-Benavidez, Hugo Alejandro Carrillo, Jeison Alexander Ramos-Sepúlveda, Emilio Villa-González, and Antonio García-Hermoso analyzed the data and wrote the paper. All authors read and approved the final manuscript.

Conflicts of Interest: The authors declare no conflict of interest.

\section{Abbreviations}

The following abbreviations are used in this manuscript:

$\begin{array}{ll}\text { BAI } & \text { Body adiposity index } \\ \text { BF\% } & \text { Body fat percentage } \\ \text { BMI } & \text { Body mass index } \\ \text { CEMA } & \text { Centre of Studies in Physical Activity Measurements (In Spanish) } \\ \text { DEXA } & \text { Dual-energy X-ray absorptiometry } \\ \text { LMICs } & \text { Low-to-middle income countries } \\ \rho c & \text { Lin's concordance correlation coefficient } \\ R^{2} & \text { Coefficient of determination } \\ \text { WC } & \text { Waist circumference } \\ \text { WHtR } & \text { Waist-to-height ratio }\end{array}$

\section{References}

1. Bhupathiraju, S.N.; Hu, F.B. Epidemiology of Obesity and Diabetes and Their Cardiovascular Complications. Circ. Res. 2016, 118, 1723-1735. [CrossRef] [PubMed] 
2. Lam, B.C.; Koh, G.C.; Chen, C.; Wong, M.T.; Fallows, S.J. Comparison of Body Mass Index (BMI), Body AdiposityIndex (BAI), Waist Circumference (WC), Waist-To-Hip Ratio (WHtR) and Waist-To-Height Ratio (WHtR) as predictors of cardiovascular disease risk factors in an adult population in Singapore. PLoS ONE 2015, 10, e0122985. [CrossRef] [PubMed]

3. Antonopoulos, A.S.; Oikonomou, E.K.; Antoniades, C.; Tousoulis, D. From the BMI paradox to the obesity paradox: The obesity-mortality association in coronary heart disease. Obes. Rev. 2016, 17, 989-1000. [CrossRef] [PubMed]

4. Gregg, E.W.; Cheng, Y.J.; Cadwell, B.L.; Imperatore, G.; Williams, D.E.; Flegal, K.M.; Narayan, K.M.; Williamson, D.F. Secular trends in cardiovascular disease risk factors according to body mass index in US adults. JAMA 2005, 293, 1868-1874. [CrossRef] [PubMed]

5. Saydah, S.; Bullard, K.M.; Cheng, Y.; Ali, M.K.; Gregg, E.W.; Geiss, L.; Imperatore, G. Trends in cardiovascular disease risk factors by obesity level in adults in the United States, NHANES 1999-2010. Obes. Silver Spring 2014, 22, 1888-1895. [CrossRef] [PubMed]

6. Lee, S.Y.; Gallagher, D. Assessment methods in human body composition. Curr. Opin. Clin. Nutr. Metab. Care 2008, 11, 566-572. [CrossRef] [PubMed]

7. Lloret Linares, C.; Ciangura, C.; Bouillot, J.L.; Coupaye, M.; Declèves, X.; Poitou, C.; Basdevant, A.; Oppert, J.M. Validity of leg-to-leg bioelectrical impedance analysis to estimate body fat in obesity. Obes. Surg. 2011, 21, 917-923. [CrossRef] [PubMed]

8. Browning, L.M.; Mugridge, O.; Dixon, A.K.; Aitken, S.W.; Prentice, A.M.; Jebb, S.A. Measuring abdominal adipose tissue: Comparison of simpler methods with MRI. Obes. Facts 2011, 4, 9-15. [CrossRef] [PubMed]

9. Bergman, R.N.; Stefanovski, D.; Buchanan, T.A.; Sumner, A.E.; Reynolds, J.C.; Sebring, N.G.; Xiang, A.H.; Watanabe, R.M. A better index of body adiposity. Obes. Silver Spring 2011, 19, 1083-1089. [CrossRef] [PubMed]

10. Geliebter, A.; Atalayer, D.; Flancbaum, L.; Gibson, C.D. Comparison of body adiposity index (BAI) and BMI with estimations of \% body fat in clinically severe obese women. Obes. Silver Spring 2013, 21, 493-498. [CrossRef] [PubMed]

11. Bernhard, A.B.; Scabim, V.M.; Serafim, M.P.; Gadducci, A.V.; Santo, M.A.; de Cleva, R. Modified body adiposity index for body fat estimation in severe obesity. J. Hum. Nutr. Diet. 2016. [CrossRef] [PubMed]

12. Ezeukwu, A.O.; Ezeoranu, C.G.; Egwuonwu, A.V.; Ugwoke, U.M.; Ekechukwu, N.E.; Nwankwo, M.J. Comparison of Body Fat Percentages in Nigerian Obese Females Using Field Methods. J. Health Sci. 2015, 5, $18-23$.

13. Silva, M.I.; Vale, B.S.; Lemos, C.C.; Torres, M.R.; Bregman, R. Body adiposity index assess body fat with high accuracy in nondialyzed chronic kidney disease patients. Obes. Silver Spring 2013, 21, 546-552. [CrossRef] [PubMed]

14. García, A.I.; Niño-Silva, L.A.; González-Ruíz, K.; Ramírez-Vélez, R. Body adiposity index as marker of obesity and cardiovascular risk in adults from Bogotá, Colombia. Endocrinol. Nutr. 2015, 130, 130-137. [CrossRef] [PubMed]

15. Cerqueira, M.; Amorim, P.; Magalhaes, F.; Castro, E.; Franco, F.; Franceschini, S.; Cerqueira, L.; Marins, J.; Doimo, L. Validity of body adiposity index in predicting body fat in a sample of Brazilian women. Obes. Silver Spring 2013, 21, E696-E699. [CrossRef] [PubMed]

16. Kuhn, P.C.; Vieira Filho, J.P.; Franco, L.; Dal Fabbro, A.; Franco, L.J.; Moises, R.S. Evaluation of body adiposity index (BAI) to estimate percent body fat in an indigenous population. Clin. Nutr. 2014, 33, 287-290. [CrossRef] [PubMed]

17. González-Ruíz, K.; Ramírez-Vélez, R. Body adiposity index in Colombian elite athletes: A comparison between the body mass index and other measures. Rev. Colomb. Cardiol. 2015, 22, 22-26.

18. Carpio-Rivera, E.; Hernández-Elizondo, J.; Salicetti-Fonseca, A.; Solera-Herrera, A.; Moncada-Jiménez, J. Predictive validity of the body adiposity index in costarican students. Am. J. Hum. Biol. 2016, 28, 394-397. [CrossRef] [PubMed]

19. Segheto, W.; Coelho, F.A.; Guimarães da Silva, C.D.; Hallal, P.C.; Marins, J.C.; Ribeiro, A.Q.; Pessoa, M.C.; Morais, S.H.; Longo, G.Z. Validity of body adiposity index in predicting body fat in Brazilians adults. Am. J. Hum. Biol. 2016. [CrossRef] [PubMed]

20. Lopez-Jaramillo, P.; Lahera, V.; Lopez-Lopez, J. Epidemic of cardiometabolic diseases: A Latin American point of view. Ther. Adv. Cardiovasc. Dis. 2011, 5, 119-131. [CrossRef] [PubMed] 
21. Parra, D.C.; Iannotti, L.; Gomez, L.F.; Pachón, H.; Haire-Joshu, D.; Sarmiento, O.L.; Kuhlmann, A.S.; Brownson, R.C. The nutrition transition in Colombia over a decade: A novel household classification system of anthropometric measures. Arch. Public Health 2015, 73, 12. [CrossRef] [PubMed]

22. Cetin, D.; Lessig, B.A.; Nasr, E. Comprehensive Evaluation for Obesity: Beyond Body Mass Index. J. Am. Osteopath. Assoc. 2016, 116, 376-382. [CrossRef] [PubMed]

23. Kahn, H.S.; Bullard, K.M. Beyond Body Mass Index: Advantages of Abdominal Measurements for Recognizing Cardiometabolic Disorders. Am. J. Med. 2016, 129, 74-81. [CrossRef] [PubMed]

24. Johnson Stoklossa, C.A.; Forhan, M.; Padwal, R.S.; Gonzalez, M.C.; Prado, C.M. Practical Considerations for Body Composition Assessment of Adults with Class II/III Obesity Using Bioelectrical Impedance Analysis or Dual-Energy X-ray Absorptiometry. Curr. Obes. Rep. 2016, 5, 389-396. [CrossRef] [PubMed]

25. González-Ruíz, K.; Correa-Bautista, J.E.; Ramírez-Vélez, R. Evaluation of the body adiposity index in predicting percentage body fat among Colombian adults. Nutr. Hosp. 2015, 32, 55-60. [PubMed]

26. González-Ruíz, K.; Correa-Bautista, J.E.; Ramírez-Vélez, R. Body adiposity and its relationship of metabolic syndrome components in Colombian adults. Nutr. Hosp. 2015, 32, 1468-1475. [PubMed]

27. Marfell-Jones, M.; Olds, T.; Stewart, A.; Carter, L. International Standards for Anthropometric Assessment; International Society for the Advancement of Kinanthropometry (ISAK): Potchefstroom, South Africa, 2006.

28. World Health Organization. Obesity: Preventing and Managing the Global Epidemic: Report of a WHO Consultation on Obesity; WHO: Geneva, Switzerland, 1997.

29. Tanita BC420MA Body Composition Analyser. Available online: http://tanita.eu/media/wysiwyg/ manuals/medical-approved-body-composition-monitors/bc-420ma-instruction-manual.pdf (accessed on 1 September 2016).

30. Lin, L.I. A concordance correlation coefficient to evaluate reproducibility. Biometrics 1989, 45, $255-268$. [CrossRef] [PubMed]

31. Bland, J.M.; Altman, D.G. Statistical methods for assessing agreement between two methods of clinical measurement. Lancet 1986, 8476, 307-310. [CrossRef]

32. López, A.A.; Cespedes, M.L.; Vicente, T.; Tomas, M.; Bennasar-Veny, M.; Aguilo, A. Body Adiposity Index Utilization in a Spanish Mediterranean Population: Comparison with the Body Mass Index. PLoS ONE 2012, 7, e35281. [CrossRef] [PubMed]

33. Freedman, D.S.; Thornton, J.C.; Pi-Sunyer, F.X.; Heymsfield, S.B.; Wang, J.; Pierson, R.N., Jr.; Blanck, H.M.; Gallagher, D. The body adiposity index (hip circumference $\div$ height (1.5)) is not a more accurate measure of adiposity than is BMI, waist circumference, or hip circumference. Obes. Silver Spring 2012, 20, 2438-2444. [CrossRef] [PubMed]

34. Johnson, W.; Chumlea, W.C.; Czerwinski, S.A.; Demerath, E.W. Concordance of the recently published body adiposity index with measured body fat percent in European-American adults. Obes. Silver Spring 2012, 20, 900-903. [CrossRef] [PubMed]

35. Vinknes, K.J.; Elshorbagy, A.K.; Drevon, C.A.; Gjesdal, C.G.; Tell, G.S.; Nygård, O.; Vollset, S.E.; Refsum, H. Evaluation of the body adiposity index in a Caucasian population: The Hordaland health study. Am. J. Epidemiol. 2013, 177, 586-592. [CrossRef] [PubMed]

36. Lemacks, J.L.; Liu, P.Y.; Shin, H.; Ralston, P.A.; Ilich, J.Z. Validation of body adiposity index as a measure of obesity in overweight and obese postmenopausal white women and its comparison with body mass index. Menopause 2012, 19, 1277-1279. [CrossRef] [PubMed]

37. Lohman, T.G. Advances in Body Composition Assessment; Human Kinetics Publisher: Champaign, IL, USA, 1992.

38. Siervo, M.; Prado, C.M.; Stephan, B.C.; Lara, J.; Muscariello, E.; Nasti, G.; Colantuoni, A. Association of the body adiposity index (BAI) with metabolic risk factors in young and older overweight and obese women. Eat. Weight. Disord. 2014, 19, 397-402. [CrossRef] [PubMed]

39. Bennasar-Veny, M.; Lopez-Gonzalez, A.A.; Tauler, P.; Cespedes, M.L.; Vicente-Herrero, T.; Yanez, A.; Tomas-Salva, M.; Aguilo, A. Body adiposity index and cardiovascular health risk factors in Caucasians: A comparison with the body mass index and others. PLoS ONE 2013, 8, e63999. [CrossRef] [PubMed]

40. Dehghan, M.; Merchant, A.T. Is bioelectrical impedance accurate for use in large epidemiological studies? Nutr. J. 2008, 7, 26. [CrossRef] [PubMed] 
41. Kushner, R.F.; Gudivaka, R.; Schoeller, D.A. Clinical characteristics influencing bioelectrical impedance analysis measurements. Am. J. Clin. Nutr. 1996, 64, 4235-4275.

42. Ramírez-Vélez, R.; Correa-Bautista, J.E.; González-Ruíz, K.; Vivas, A.; García-Hermoso, A.; Triana-Reina, H.R. Predictive validity of the body adiposity index in overweight and obese adults using dual-energy $\mathrm{X}$-ray absorptiometry. Nutrients 2016, 8, 737. [CrossRef] [PubMed]

(C) 2017 by the authors; licensee MDPI, Basel, Switzerland. This article is an open access article distributed under the terms and conditions of the Creative Commons Attribution (CC-BY) license (http:/ / creativecommons.org/licenses/by/4.0/). 